\title{
地盤の大歪み領域における地盤・杭・建物連成系の 地震時挙動の簡易評価法に関する研究 \\ AN SIMPLIFIED METHOD TO ESTIMATE DYNAMIC RESPONSE OF SOIL-PILE-BUILDING INTERACTION SYSTEM IN LARGE STRAIN LEVELS OF SOILS
}

\author{
田守 伸一郎*，飯 場 正 紀**，北 川 良 和*** \\ Shin'ichiro TAMORI, Masanori IIBA and Yoshikazu KITAGAWA
}

\begin{abstract}
A series of shaking-table tests of a scaled soil-pile-building model were performed in order to study the effects of the plastic deformation of soil on dynamic characteristics of the soil-pile-building interaction system. The elasto-plastic material for model ground was made by Plasticine, whose strain dependency of the stiffness and the damping are similar to those of clayey soils. The input motion is 1968 Hachinohe EW and its maximum accelerations were set to be $100,300600 \mathrm{~cm} / \mathrm{s}^{2}$ at the shaking table. Results show the average maximum strain of soil became from 0.0018 to 0.018 and the natural frequency and the amplification factor decrease by $28 \%$ and $39 \%$, respectively. Dynamic response analyses, which combined the mass`spring model (SR model) having swaying and rocking spring and dashpots located at the foundation of the building and an equivalent linearization method, were carried out. The difference in the natural frequency obtained by the test and analyses were within $5 \%$ and those of maximum acceleration at the building are within $10 \%$.
\end{abstract}

Keywords : $\quad$ non-linear soil-pile-building interaction, Sway-Rocking model, equivalent linearization method, shaking table test 非線形地盤・杭·建物相互作用, スウェイ・ロッキングモデル, 等価線形化法, 振動台実験

\section{1. はじめに}

地盤の非線形性を含めた地盤と建物との動的相互作用効果を 考慮した構造物の地震時挙動を精度良く評価することは，耐震設 計上重要なことである。このような解析を行う手法としては有限 要素モデルやPenzien 型のモデルによる時刻歴応答解析が有効で あるが，有限要素モデルは多大な計算時間が必要となること， Penzien 型モデルでは地盤バネや杭基礎周辺の仮想質量の評価な どが難しいなどの理由により塞務設計では一般的な手法にはい たっていない。また，薄層要素法を用いた例では，杭周辺部のみ の地盤に㓮性を低下させた部分を設け，動的インピーダンスを求 めたり ${ }^{1) ， \text { 等価線形化法を適用して起振機実験結果に適用 }{ }^{2)} れ れ ~}$ ていたりしてはいるが，地震応答解析に適用するまでには至って いない。このような状況のもと，本研究では材料非線形性を有す る地盤と建物との動的相互作用効果をできるだけ簡易な解析手 法，すなわち地盤のバネを Sway-Rocking モデル(以下 SR モデル と称す)で評価し，模型地盤・杭・建物連成系を対象として行っ た振動台実験結果との比較から，この種の解析手法の妥当性につ
いて検証することを目的としている。なお，地盤バネの算定にあ たっては地盤の材料非線形性を考慮するために等価線形化法を 用いた。また，杭周辺の地盤の非線形性を考慮するためには，あ らかじめ求めておいた杭の水平変位と水平剛性の関保を上記の 等価線形解析に組み合わせる。実用的には水平地盤反力係数が杭 頭変位の平方根に反比例するような関係を利用することが考え られるが，本研究では静的 FEM 解析結果を利用した。

\section{2. 塑性地盤材料}

実験に用いた塑性地盤材料はプラスチシンである。これは炭酸 カルシウムの粉末に油を混ぜ合わせて粘土状にしたもので，その 力学的性質が高温の鋼の性質とよく似ていることから，板材圧延 など各種の加工法のモデル材料として広く用いられている ${ }^{3)}$ 。打 設した地盤材料の動的三軸圧縮試験（拘束圧 $1.0 \mathrm{kgf} / \mathrm{cm}^{2}$, 加振振 動数 $1.0 \mathrm{~Hz}$ ）の結果より得られたせん断喇性，减衰定数の歪み依 存性を図 1 (文献 4 に加筆)に示寸。図中の○印は実験に用いた材 料特性である。図からわかるように, せん断剛性, 減衰定数とも
* 信州大学工学部 助教授. 工博

** 建設省建築研究所基礎研究室 室長 · 工修

*** 広島大学工学部 教授. 工博
Assoc. Prof., Faculty of Eng., Shinshu Univ., Dr. Eng.

Head, Structural Eng. Dept., Building Res. Inst., Min. of Construction, M. Eng Prof., Faculty of Eng., Hiroshima Univ., Dr. Eng. 
実粘性土を対象とした実験結果と調和している。また，類似の塑 性地盤材料を使った試験結果 ${ }^{5)}$ より, $1 \sim 5 \mathrm{~Hz}$ 程度の振動数範囲内 では材料特性にほとんど変化がなく，周波数俵存性はないことを 確認している。

\section{3. 実験概要}

建物の原型は 11 階建鉄筋コンクリート造構造物（以下 HFW 建 物之称す)である ${ }^{\mathrm{B})}$ 。 $\mathrm{HFW}$ 建物の構造形式は桁行方向が扁平な壁 柱と同じ厚さのはりからなる壁式ラーメン構造で, 梁間方向が両 端に壁柱を有する独立耐震壁構造である。模型の相似比の決定に あたっては，長さ，加速度，密度を設定相似比とし，他の物理量 は次元にしたがって誘導した。相似比を表 1 に示す。図 1 からわ かるように，模型地盤材料のせん断剛性と減衰定数は実際の粘性 土と類似の歪み依存性を有しているため, 地盤歪みの広い領域内 で相似則が保たれていると考えられる。

模型建物は原型の梁間方向 2 スパン分を相似則にしたがって モデル化し，板バネの柱と床位置での重りを用いて製作した。模 型基礎はアクリルとアルミ板製である。杭は鋼板製で，地表面下 $-45 \mathrm{~cm}$ を支持層とした。このとき，杭先端部に鋼製の板を取り付 けた後，杭周辺にゴムを張り付けて円柱状（直径 : $38 \mathrm{~mm}$, 長さ： 487mm）とした。なお，模型基礎底面と地盤とは分離しており， 基礎は杭のみによって支持されている。模型試験体断面図と計測 器の配置を図 2 に, 模型建物の基礎固定時の固有振動数, 减衰定 数を表 2 に示す。杭の曲げ凪性，减衰定数は杭頭を固定した自由 振動試験から評価した。曲げ剖性は 41.9 42.4tf. $\mathrm{cm}^{2}$, 堿衰定数 は $0.52 \sim 2.1 \%$ ある。

模型地盤は概ね $2 \times 1.5 \times 0.6 \mathrm{~m}$ の直方体であり，外周部にポリ アクリルアマイドとベントナイトを基本材料とした弾性体部分 と，その中央部に直径 $0.8 \mathrm{~m}$ ，厚さ $0.367 \mathrm{~m}$ の円柱状のプラスチシ ンを材料とした塑性体部分から構成されている。地盤が害地盤に 近い状態でせん断変形するためには地盤の高さに対してある程 度平面の広がりを持つようにする必要があるが, プラスチシンを 大量に製作する事が困難なことから，特に建物の周辺部のみにこ れを使用することとした。建物周辺部は基礎の根入れ効果を無く するため, プラスチシンの部分は地表面から $8.3 \mathrm{~cm}$ の哚さまで削

表 1 相似比

\begin{tabular}{|ll|c|c|}
\hline \multicolumn{2}{|c|}{ Item } & \multicolumn{2}{c|}{ Ratio(Model/Prototype) } \\
\hline Soil Density & $\mathrm{kgf} / \mathrm{cm}^{3}$ & $1 / \eta$ & 1 \\
Length & $\mathrm{cm}$ & $1 / \lambda$ & $1 / 40$ \\
Acceleration & $\mathrm{cm} / \mathrm{s}^{2}$ & 1 & 1 \\
\hline Displacement & $\mathrm{cm}$ & $1 / \lambda$ & $1 / 40$ \\
Mass & $\mathrm{kgf.s} / \mathrm{cm}$ & $1 / \eta \lambda^{3}$ & $1 / 6.4 \times 10^{4}$ \\
Shear Modulus & $\mathrm{kgf} / \mathrm{cm}^{2}$ & $1 / \eta \lambda$ & $1 / 40$ \\
Frequency & $1 / \mathrm{s}$ & $\sqrt{ } \lambda$ & 6.325 \\
Velocity & $\mathrm{cm} / \mathrm{s}$ & $1 / \sqrt{ } \lambda$ & $1 / 6.325$ \\
Stress & $\mathrm{kgf} / \mathrm{cm}^{2}$ & $1 / \eta \lambda$ & $1 / 40$ \\
Strain & & $\mathbf{1}$ & 1 \\
& & & \\
\hline
\end{tabular}
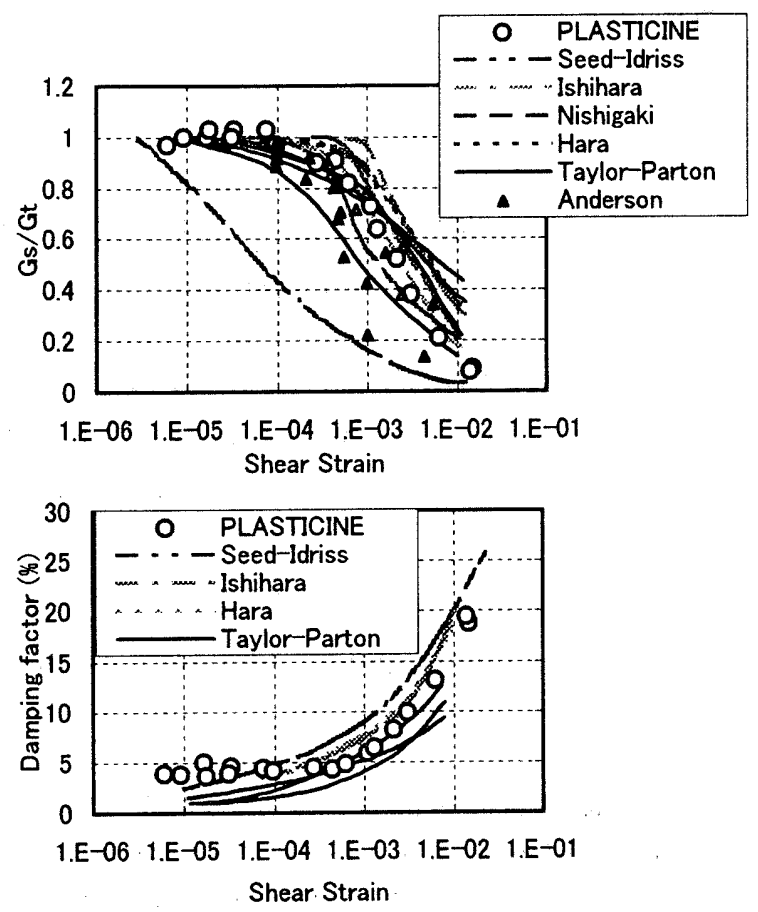

図1 模型地盤材料の特性

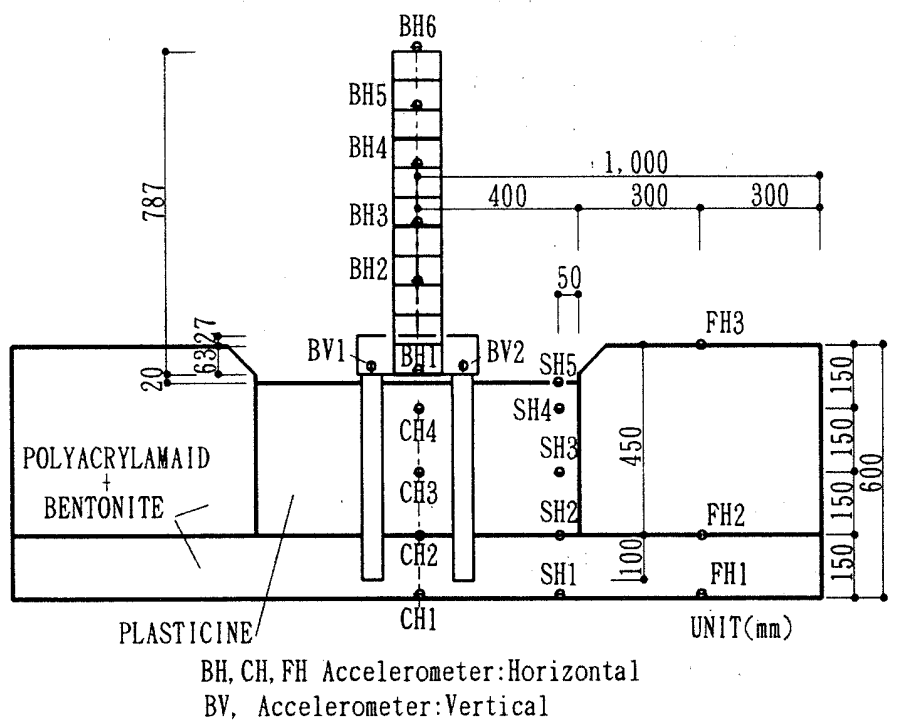

図 2 模型試験体断面と計測機器配置

表 2 建物模型の諸元

\begin{tabular}{|c|c|c|c|c|c|}
\hline \multicolumn{2}{|c|}{ Foundation } & \multicolumn{2}{|c|}{ Building } & \multicolumn{2}{|c|}{$\begin{array}{c}\text { Characteristics } \\
\text { of Fixed Base } \\
\text { Building }\end{array}$} \\
\hline $\begin{array}{c}\text { Size } \\
(\mathrm{cm})\end{array}$ & $\begin{array}{c}\text { Weight } \\
(\mathrm{kgf})\end{array}$ & $\begin{array}{c}\text { Height } \\
(\mathrm{cm})\end{array}$ & $\begin{array}{c}\text { Weight } \\
(\mathrm{kgf})\end{array}$ & $\begin{array}{c}\text { Natural } \\
\text { Freq. } \\
(\mathrm{Hz})\end{array}$ & $\begin{array}{c}\text { Damping } \\
\text { Factor } \\
(\%)\end{array}$ \\
\hline $\begin{array}{c}30 \\
\times\end{array}$ & 6.79 & 78.7 & 28.4 & 18.8 & 0.22 \\
\hline
\end{tabular}

表 3 模型地盤の特性

\begin{tabular}{|c|c|c|c|}
\hline \multirow{2}{*}{ Item } & \multicolumn{2}{|c|}{$\begin{array}{c}\text { Upper Layer } \\
(\mathrm{GL} \sim \mathrm{GL}-45 \mathrm{~cm})\end{array}$} & \multirow{2}{*}{$\begin{array}{c}\text { Lower Layer } \\
(\mathrm{GL}-45 \sim 60 \mathrm{~cm})\end{array}$} \\
\cline { 2 - 3 } & Center & Edge & \\
\hline Vs(m/s) & 23.7 & 18.4 & 36.0 \\
Damping Factor(\%) & $6.63 *$ & 5.57 & 6.05 \\
Density(gf/cm $\left.{ }^{3}\right)$ & 1.57 & 1.17 & 1.41 \\
\hline
\end{tabular}


り取られている。また, 塑性体部分と弾性体部分との境界位置に は法面を設けている。地盤の振動方向の両端部断面全面に幅 $1.5 \mathrm{~m}$, 高さ $60 \mathrm{~cm}$, 厚さ $2 \mathrm{~mm}$ のステンレス板をそれぞれ 1 枚づつ設置した うえで，2枚のステンレス板の上端部を軽量型鋼で連結した。こ の装置の目的は地盤両端部での地盤の上下方向の変形を押さえ ること, 地盤の左右の上端部での水平変位を同一にすることによ って地盤がせん断変形しているのに近い状態を作り出すためで ある。地盤特性を表 3 に示す。ここで減衰定数は地盤材料のテス トピースでの自由るじり試験, せん断波速度は PS 検層試験より 得られたものである。計測項目は地盤, 基礎, 建物内での加速度 である(図 2 参照)。加速度計(動ひずみ型) は建物内 6 点, 基礎 内 5 点, 地盤内 12 点である。

振動台実験は観測地震動波形(1968 Hachinohe EW)を用いたラ ンダム加振とし, 最大加速度を振動台テーブル上でおよそ $100,300,600 \mathrm{~cm} / \mathrm{s}^{2}$ の 3 段階に設定した。入力地震動の時間軸は相 似則にしたがって $1 / \sqrt{ } 40$ とした。なお，振動台は $3 \times 4 \mathrm{~m}$ のテー ブルを有する油圧式一軸で, 最大 20 ton 積載時で $1 \mathrm{G}$ 加振が可能 である。振動台の駆動時には入力補償システムを使用している。

\section{4. 模型地盤の歪みと連成系の動特性の関係}

図 3,4 に地盤の最大歪みの平均值と, 地表面 (SH5) と建物頂部 (BH6) とのスペクトル比 (BH6/SH5, 図 2 参照)のピーク位置から定 まる一次固有振動数およびその振幅比を示す。ここで地盤の最大 せん断歪みの平均值は以下のように算定した。まず, 地表面 (SH5) と地中 3 点 $(\mathrm{SH} 4, \mathrm{SH} 3, \mathrm{SH} 2)$ の加速度記録を 2 回積分し変位に変 換した後, SH5-SH4,SH4-SH3 および SH3-SH2 間の変位差の最大値 をそれぞれの加速度計間の距離で除すことによって平均せん断 歪みを算定した。さらに, SH5-SH4, SH4-SH3，SH3-SH2 間のせん 断歪みを加速度計間の距離の重み付きで平均し, 地盤の最大歪み の平均值とした。この地盤の歪みは地盤の入・反射波動場による 歪みを意味すると解釈し, 後述の式(5)の $\gamma_{\text {wave }}$ に相当するとみな した。これらの図から分かるように，入力加速度の最大值が $100,300,600 \mathrm{~cm} / \mathrm{s}^{2}$ と増加するにしたがい，地盤の最大歪みの平均 值は $0.0018 \sim 0.018$ 程度に増加している。これにともなって連成 系一次固有振動数波は $8.25 \mathrm{~Hz}$ から $6.0 \mathrm{~Hz}$ 个，地表面にたい寸る 建物頂部での応答倍率は 7.1 から 4.3 程度へ変化している。すな わち $100 \mathrm{~cm} / \mathrm{s}^{2}$ 入力の場合と比較すると $600 \mathrm{~cm} / \mathrm{s}^{2}$ 入力の場合は一 次固有振動数と応答倍率はそれぞれ $72 \% ， 61 \%$ に低下している。

\section{5. 解析モデル}

地震応答解析の解析モデルとして SR モデルを採用し，地盤の 材料非線形性を考慮するために等価線形化法を用いた。なお, 解 析にあたっては地震動の入力位置は地表面とし, SH5 地点（図 2

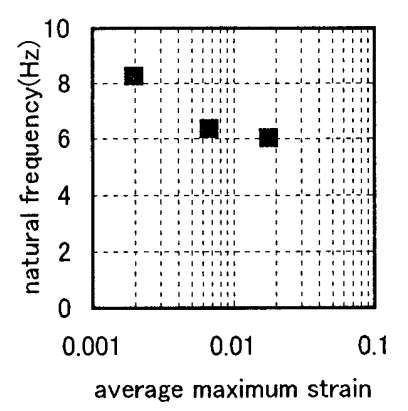

図 3 一次固有振動数と地盤の 最大歪みの平均値

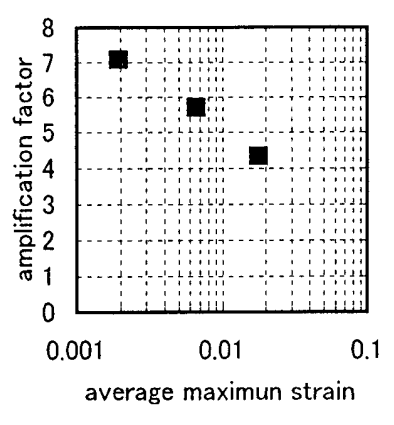

図4 応答倍率と地盤の最大 歪みの平均值
参照）で得られた加速度記録を用いた。

地盤バネの算定 SR モデルの地盤バネは以下のように定めた。 1）杭の水平・回転バネは地盤を水平方向に無限に広がる均質な弾 性体と仮定し，これに波動方程式を適用した Novak 他 ${ }^{7)}$ の手法を 用い, 振動数依存性を考慮する。杭の水平バネは文献 8 の手法に したがって群杭効果を考慮する。この場合の群杭効率は 0.72 と なった。

2）杭の鉛直バネは, Novak $^{8)}$ の手法を用いる。この手法は地盤の 条件は水平回転ばねと同様であるが, 地盤の平面歪みを仮定して いるため, 低振動数領域で䣓性の実部を過小に, 㑉性の虚部を過 大に評価することが知られている。そこで, 杭側面部分の剛性に ついては無次元化振動数 $\left(a_{0}=r_{0} \omega / V_{s}, こ こ に r_{0}\right.$ : 杭の半径, $\omega$ : 円振動数, $V_{s}$ : 地盤のせん断波速度) が 0.3 以下の範囲では㓝性の 実部を一定とした。また, 剛性の虚部は無次元化振動数ゼロで値 がゼロであるとし, 無次元化振動数 0.3 までは振動数に比例する ように修正を加えた。

塑性地盤材料の歪み依存性 塑性地盤材料の剛性 - 減哀性の歪 み依存性は以下のようにモデル化した。

地盤のせん断剛性 $\left(G_{s}\right) \cdot$ 減衰定数 $\left(h_{g}\right)$ の歪み依存性は地盤材料 の動的三軸圧縮試験結果 (図 1) を元に Hardin-Drnevich の定式化 を参考に(1) (2)式のように設定した。

$$
\frac{G_{s}}{G_{t}}=\frac{1.01}{1+0.96\left(r_{s} / 0.002072\right)^{1.258}}
$$

$$
h_{g}=0.035+0.145\left(1-G_{s} / G_{t}\right)
$$

ここに，G $G_{t}$ は初期せん断剛性， $\gamma_{s}$ はせん断歪みである。

地盤の非線形性と剛性・減衰性の評価 地盤の非線形性は地盤 の入・反射波動場によるもの（サイト・ノンリニアリティー）と 建物慣性力によって生ずる杭と周辺地盤の相対变位によるもの （ローカル・ノンリニアリティー）から成ると考える。地盤の入． 反射波動場による歪み $(\gamma$ wave $)$ は地震の際, 建物がない自由地 盤内で発生寸る歪みに相当する。本研究では， $\gamma_{\text {wave }}$ は実験值で あり,前出の図 3,4 で示した地盤の最大歪みの平均值を採用した。 杭一地盤間の相対変位による杭周辺部の地盤の非線形性は以下 
のように評価した。まず，あらかじめ静的 FEM 解析によって杭頭 の変位と水平地盤反力係数の関係を求め, これを利用する。静的 FEM 解析は汎用 FEM 解析ソフトである ANSYS を用いた。解析モデ ルを図 5 に示寸。地盤は半径 $50 \mathrm{~cm}$ ，層厚 $51 \mathrm{~cm}$ （下層部 $15 \mathrm{~cm} ，$ 上 層部 $36 \mathrm{~cm}$ ), 杭長さは地盤中の埋め込み長さの $46 \mathrm{~cm}$ とし, 加力方 向直交方向に対称な $1 / 2$ モデルとした。図中の中央部分が杭であ り，地盤は模型試験体に基づいて上層，下層部分をもうけた。更 に，杭近傍の地盤特性が解析に与える影響が大きいと判断し弹塑 性模型地盤材料が最外縁まで続いていると仮定した。要素分割に あたっては，媣さ方向は上層部分で 15 分割，下層部分で 5 分割 であり，水平方向は杭内部を 8 分割，杭の外周から $4 \mathrm{~cm}$ まで， 4 〜8. $1 \mathrm{~cm}$ まで， $8.1 \mathrm{~cm}$ 地盤の最外縁までをそれぞれ 4 分割した。 円周方向は 8 分割とした。要素数は 2184, 節点数 10257 である。 要素の設定においては地盤の上層部分のみ弾塑性要素とし， Drucker-Prager の降伏条件を適用した。この部分の粘着力は模型 地盤材料の動的三軸圧縮試験結果から $0.02 \mathrm{kgf} / \mathrm{cm}^{2}$, 内部摩擦角 は $0^{\circ}$ とした。境界条件としては地盤底面と円周部分を固定とし た。解析にあたってはパイルキャップ部の回転変位を拘束した上 で，ここに水平力を加え，荷重 $(P)$ とパイルキャップの水平変位 （y）との関係が式(3)（いわゆるChang の式）であることから水平地 盤反力倸数 $\left(k_{h s}\right)$ を求めた。

$$
P=4 E I\left(\sqrt[4]{\frac{k_{h s} D}{4 E I}}\right)^{3} y
$$

ここに, $E I$ :杭の曲げ刪性, $D$ : 杭径。

杭頭の水平変位と水平地盤反力係数の関倸を図 6 に示す。図中 の縦軸は水平地盤反力係数比であり，初期水平地盤反力係数で他 の場合の水平地盤反力係数を除したものである。図から分かるよ うに，変位が $0.006 \mathrm{~cm}$ 以下では係数比は 1 であり，この範囲では 地盤は弾性体とみなすことができる。また，図７に変位を相似則 にしたがって原型での変位に読み替えた後, これと変位が $1 \mathrm{~cm} の$ 時の水平地盤反力係数との比 (図中の実線)を示す。図中の波線は 水平地盤反力倸数が変位の平方根に反比例するとした場合の水 平地盤反力係数の比であり, 杭頭変位による水平地盤反力係数を 補正する際によく使われる関係である。両者は変位が $0.5 \mathrm{~cm} \sim$ $4.0 \mathrm{~cm}$ 程度の範囲内では調和的である。

この結果から杭頭変位と水平地盤反力倸数比（水平地盤反力倸 数/初期水平地盤反力係数）との関係を近似すると式(4) となる。

$$
\frac{k_{h s}}{k_{h 0}}=\frac{1-0.03741}{1+\left(\delta_{p} / 0.05108\right)^{1.4856}}+0.03741
$$

ここに, $k_{h o}$ : 初期水平地盤反力倸数, $k_{h s}$ :ある杭頭変位における 水平地盤反力係数, $\delta p$ :杭頭水平変位。

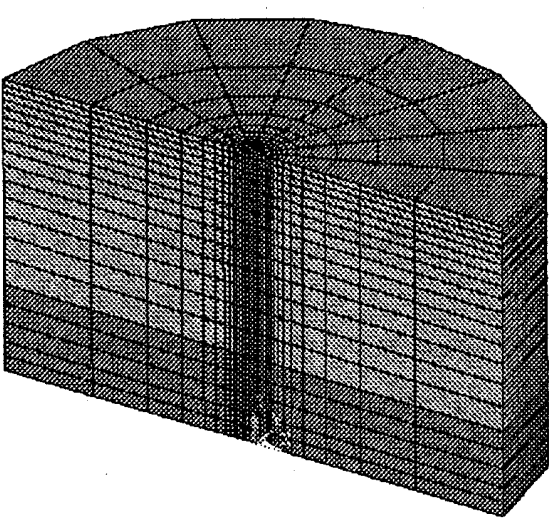

図 5 FEM モデル

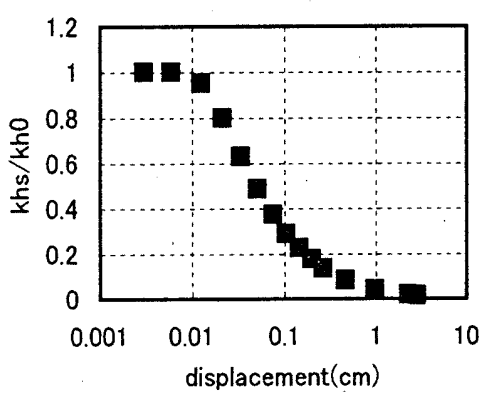

図6 杭頭水平変位と水平地盤反力係数比

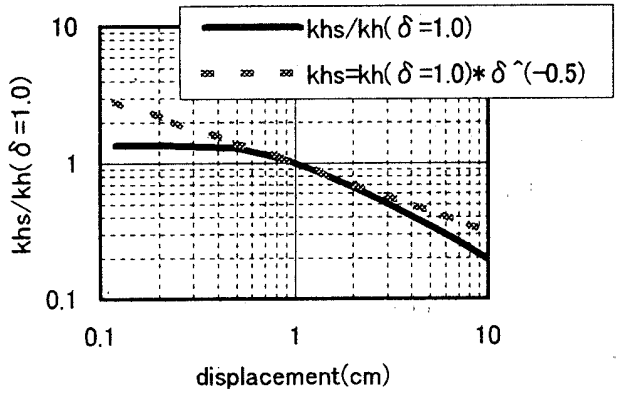

図7 杭頭水平変位と水平地盤反力係数比 (変位を原型に読み替えた場合)

地盤の非線形を評価するには地盤の入・反射波動場によるもの と式(4)で示される杭頭と地盤との水平变位による剛性低下の効 果を足し合わせる必要がある。しかしながら前者は地盤のせん断 歪で評価されるが, 水平地盤反力係数の低下の割合が杭頭変位で 評価されるためにこれらを単糺に足し合わせることはできない。 そこで，まず，地震応答解析より得られた基礎と地表面との最大 相対変位を $\delta_{p}$ として, 式(4)から水平地盤反力係数の低减率を求 める。次に，水平地盤反力係数が地盤のせん断㴊性に比例すると 考え, 水平地盤反力係数の低減率を式(1)の地盤のせん断剛性の 低減率とみなしてせん断歪を逆算する。この歪みを杭と地盤の相 対変位による地盤の非線形性を評価するための等価な歪 $\left(\gamma_{p}\right)$ と 見なすことにした。地盤の剛性と減衰定数を定めるための等価歪 
み $\left(\gamma_{\theta q}\right)$ は $\gamma_{p}$ と地盤の入・反射波動場による歪み $\left(\gamma_{\text {wave }}\right)$ と足し あわせ，式(5)で計算した。

$$
\gamma_{e q}=\alpha \sqrt{\gamma_{\text {wave }}^{2}+\gamma_{p}^{2}}
$$

ここに， $\alpha$ は地震時の地盤や基礎の応答振幅における非定常性 を考慮するための係数である。

$\gamma_{\text {wave }}$ と $\gamma_{p}$ を足し合わせるときに単純和としなかったのは地盤 のせん断歪と杭と地盤の相対変位が同時に最大になることがな かったからである。なお，式(5)により歪みを計算するのは杭の 回転・水平剛性を計算する際の地盤定数を決定する場合であり， 杭の鉛直剛性を計算する際は地盤の歪みは $\alpha$ に $\gamma_{\text {wave }}$ を乗じたも のを使用した。これは $\gamma_{p}$ が杭の水平変位による地盤の剛性低下 を評価していることによっている。

\section{6. 解析結果}

図 8 に建物頂部(BH6:図 2 参照)の地表面(SH5)に対寸るスペク トル比から求めた (a)一次固有振動数, (b) 一次固有振動数におけ る応答倍率, (c) 建物頂部での最大応答加速度值を示す。こで, 式(5)にお孫数は等価線形化法を用いる際に一般的である值 である 0.7 を採用している。一次固有振動数における解析值と実 験值との比（解析值/実験值）は $100,300 \mathrm{~cm} / \mathrm{s}^{2}$ 入力の場合はそれ ぞれ0.9〜1.04 となっており, 実験值と解析值は調和的であるが， $600 \mathrm{~cm} / \mathrm{s}^{2}$ になる 0.89 と $10 \%$ 程度の誤差となる。応答倍率をみると， 解析值と実験值との比は 0.84 1. 09, 建物頂部の最大忘答加速度 值はこの比が $0.72 〜 1.10$ となっている。このように $100 \mathrm{~cm} / \mathrm{s}^{2}$ の 入力の場合, 実験值と解析值の対応関係は一次固有振動数, 応答 倍率，最大応答加速度值のいずれにおいても調和的である。 $300 \mathrm{~cm} / \mathrm{s}^{2}$ 入力の場合, 応答倍率の解析値と実験値の比は 0.86 と 14\%程度の誤差があるものの, 最大応答加速度の解析值と実験值 の比は 0.93 と実験值と解析值は調和的である。 $600 \mathrm{~cm} / \mathrm{s}^{2}$ 入力の 場合，解析において忘答倍率は実験值と調和的であるが，一次固 有振動数を評価する際の誤差が大きく，その結果，建物頂部の最 大応答加速度値評価に $28 \%$ 程度の誤差を生ずることとなった。 $600 \mathrm{~cm} / \mathrm{s}^{2}$ 入力の場合に解析で最大加速度応答值の推定誤差が 大きかったため応答の非定常性に検討を加えた。まず，基礎と地 表面との相対変位の振幅の非定常性を式 (6)，（7) を用いて検討し た。

$$
\begin{gathered}
\beta=\frac{\sqrt{\int_{T_{1}}^{T_{2}} u_{b}^{2}(t) d t /\left(T_{2}-T_{1}\right)}}{u_{b, \max }} \\
E\left(T_{3}\right)=\int_{0}^{T_{3}} u_{b}^{2}(t) d t
\end{gathered}
$$

ここに $u_{b}(t)$ は基礎 (BH1) と地表面(SH5)の相対変位の時刻歴, $u_{b, \text { max }}$ はこれの最大值, $T_{1}, T_{2}$ は時刻歷の二乗和を計算する際の開 始時刻と終了時刻である。

表 4 基礎と地表面の相対変位にお林る非定常性

\begin{tabular}{|c|c|}
\hline $\begin{array}{c}\text { Maximum input } \\
\text { acc. }\left(\mathrm{cm} / \mathrm{s}^{2}\right)\end{array}$ & $\beta$ in equation (6) \\
\hline 100 & 0.378 \\
\hline 300 & 0.267 \\
\hline 600 & 0.216 \\
\hline
\end{tabular}

式(7) で示す時刻 $0 \sim T_{3}$ までの二乗和と全記録時間(10 秒)での 值 $(E(10.0))$ との比が 0.05 になった時の時刻が $T_{1}, 0.95$ になった ときの時刻が $T_{2}$ である。正弦波のような定常的な波形を用いて周 期の整数倍の時間で計算すると式(6)の $\beta$ は $1 / \sqrt{ } 2$ となるが，地 震動波形の場合，振幅の非定常性から值はそれより小さくなる。 結果を表 4 に示す。本実験での $\beta$ は正弦波の $0.535 \sim 0.305$ 倍程 度となっている。また, $600 \mathrm{~cm} / \mathrm{s}^{2}$ 入力の場合は $100 \mathrm{~cm} / \mathrm{s}^{2}$ 入力の場 合の 0.58 倍になり入力加速度が増加するにしたがい非定常性は 強くなっていく。

図 9 に地盤の入・反射波動場による歪の時刻歴（図中のwave） と, 建物基礎と地表面との相対変位の時刻歴（図中の relative displacement）を示す。地盤の入・反射波動場による歪の時刻歴 波形は図 4 で示した地盤の歪みの時刻歴である。なお，図 9 では 振幅の最大值が 1 になるように基準化している。これを見ると $100 \mathrm{~cm} / \mathrm{s}^{2}$ 入力の場合，わずかながら両者に位相差があり，また， このことが式(5)において地盤の入・反射波動場による歪と建物 基礎と地盤との相対変位による地盤歪を足し合わせる際に二乗 和平方根をとることの根拠ともなっている。なお， SH5-SH4， SH4-SH3，SH3-SH2での地盤歪みの時刻歷の位相差はお互いに非常 に小さく, 図 9 における位相差は杭頭近傍の波動による地盤歪み と基礎と地盤との相対変位との位相差とみなすことができた。一 方, $300 \mathrm{~cm} / \mathrm{s}^{2}$ 入力では 2.1 秒付近と 2.2 秒付近に振幅の大きな波 形があり,これらの時刻における位相差は $100 \mathrm{~cm} / \mathrm{s}^{2}$ 入力の場合よ りも大きいことがわかる。さらに $600 \mathrm{~cm} / \mathrm{s}^{2}$ 入力ではこの傾向はさ らに顕著になり 2 秒付近では両者の位相はほとんど逆転してい る。このため入力加速度が増加するに従い，基礎の水平応答の振 幅における非定常性は増加し, 地盤の歪において[波動分]と[基 礎と地盤との相対変位分]との位相差が大きくなる。これらの点 を考慮して以下に $600 \mathrm{~cm} / \mathrm{s}^{2}$ 入力において式(5)の係数 $\alpha$ を 0.7 よ り小さくする解析を実施した。

図 10 に $600 \mathrm{~cm} / \mathrm{s}^{2}$ 入力の場合に $\alpha$ を $0.6 \sim 0.4$ とした結果を示す。 解析值/実験值の比は一次固有振動数において $0.92 \sim 1.01$, であ り，応答倍率および最大応答加速度においてはそれぞれ $1.01 〜$ 


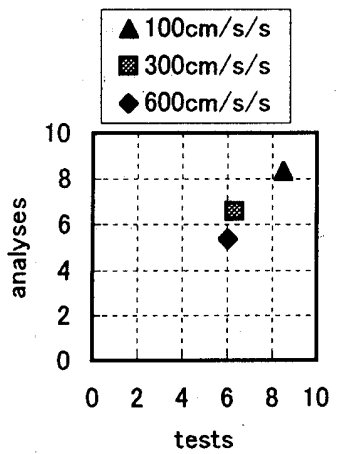

(a) natural frequency $(\mathrm{Hz})$

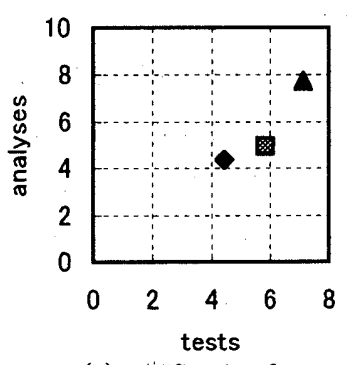

(b)amplification factor

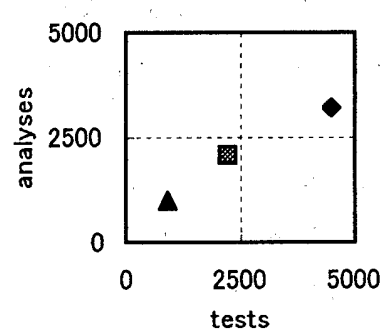

(c) maximum acc

$(\mathrm{cm} / \mathrm{s} / \mathrm{s})$

図8 実験値と解析値の比較 $(\alpha=0.7)$

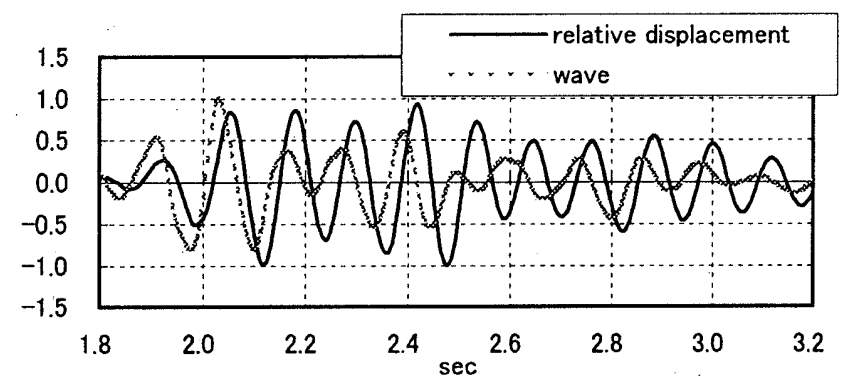

(a) $100 \mathrm{~cm} / \mathrm{s} / \mathrm{s}$

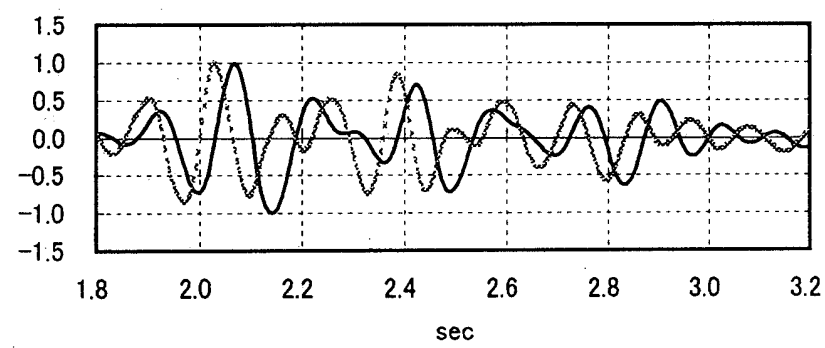

(b) $300 \mathrm{~cm} / \mathrm{s} / \mathrm{s}$

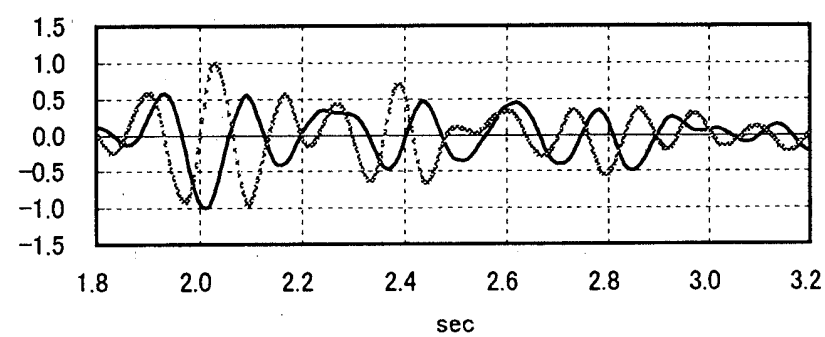

(c) $600 \mathrm{~cm} / \mathrm{s} / \mathrm{s}$

図9 地盤の入・反射波動場による歪みと基礎と地盤の相対変 位の時刻歷

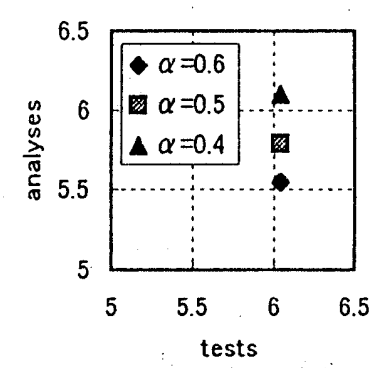

(a) natural frequency $(\mathrm{Hz})$
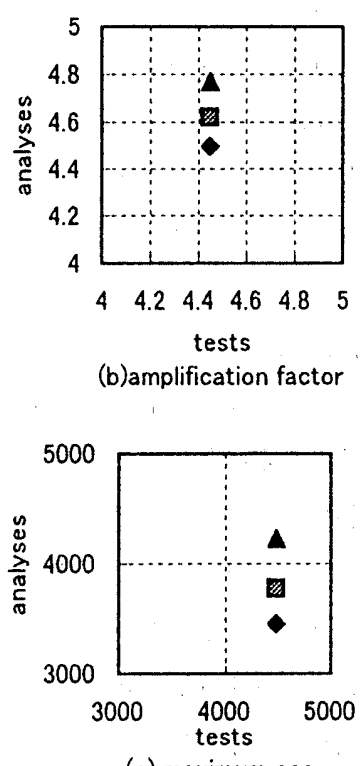

(c) maximum acc $(\mathrm{cm} / \mathrm{s} / \mathrm{s})$

図10 実駼値と解析値の比較 $(600 \mathrm{~cm} / \mathrm{s} / \mathrm{s})$

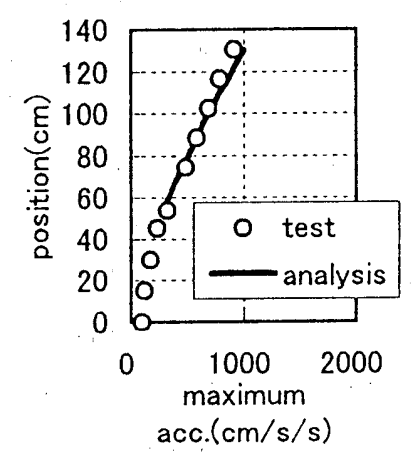

(a) $100 \mathrm{~cm} / \mathrm{s} / \mathrm{s}$

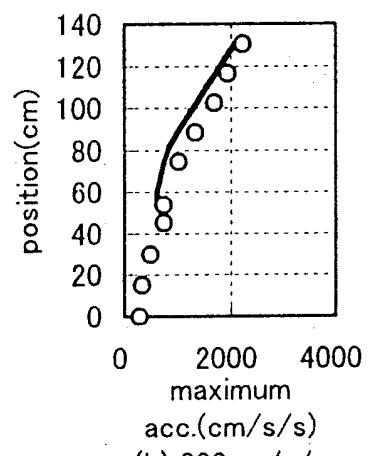

(b) $300 \mathrm{~cm} / \mathrm{s} / \mathrm{s}$

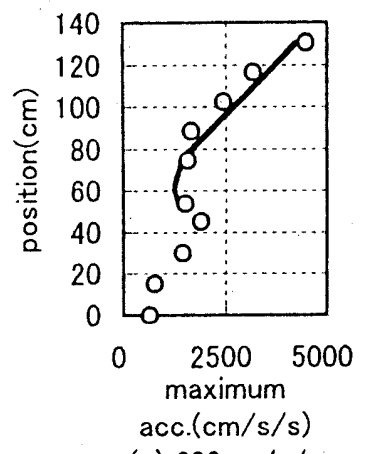

(c) $600 \mathrm{~cm} / \mathrm{s} / \mathrm{s}$

图11 最大応答加速度分布
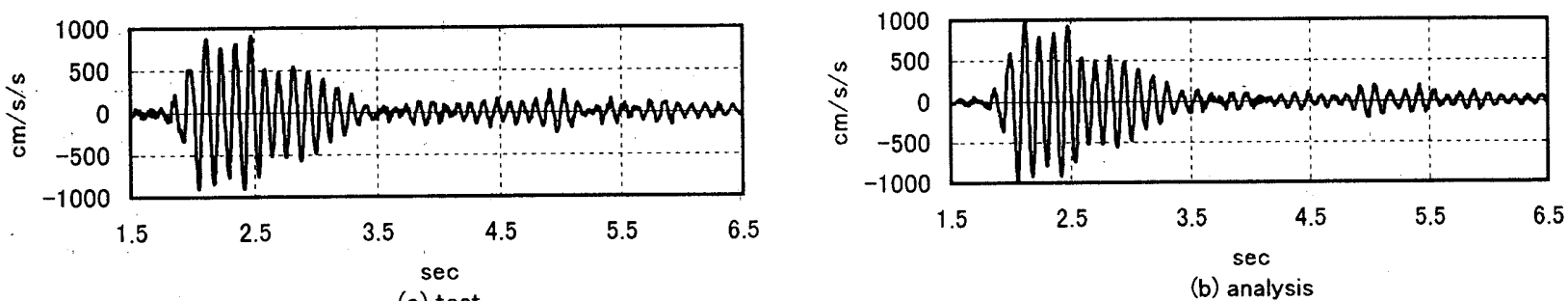

(a) test

図12 建物頂部の時刻歴応答波形 $(100 \mathrm{~cm} / \mathrm{s} / \mathrm{s})$ 


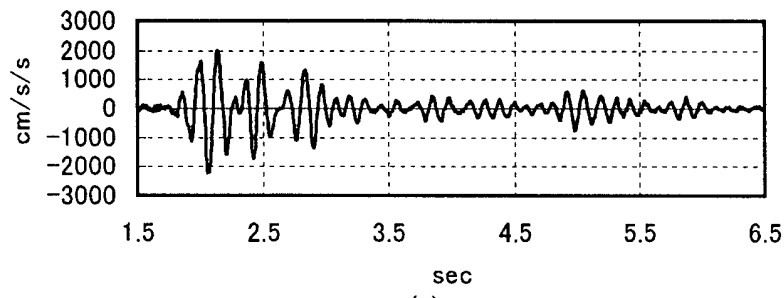

(a) test

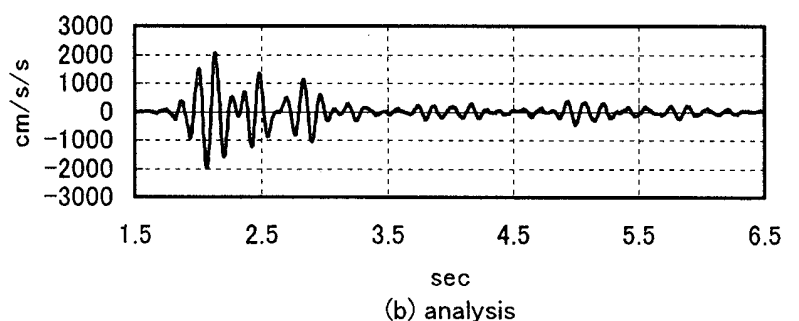

図 13 建物頂部の時刻歴応答波形 $(300 \mathrm{~cm} / \mathrm{s} / \mathrm{s})$

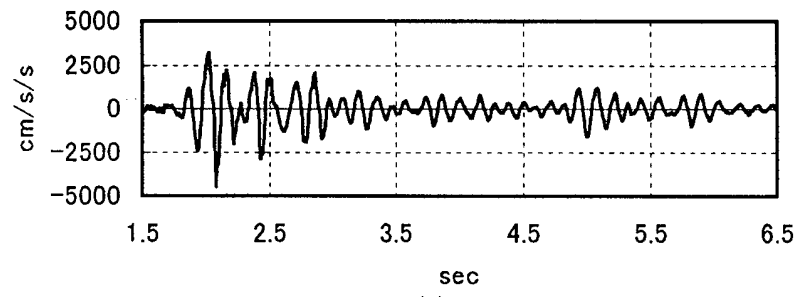

(a) test

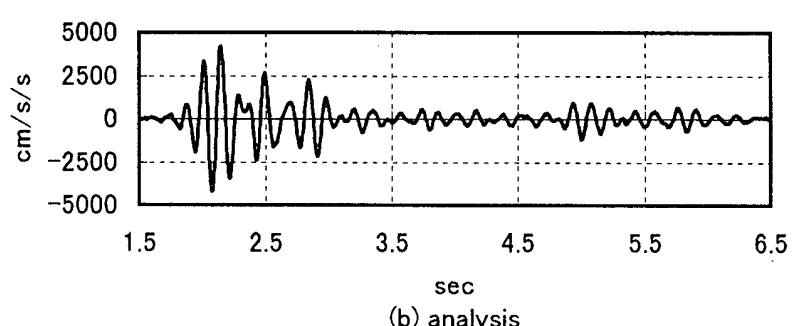

(b) analysis

図 14 建物頂部の時刻歴応答波形 $(600 \mathrm{~cm} / \mathrm{s} / \mathrm{s})$

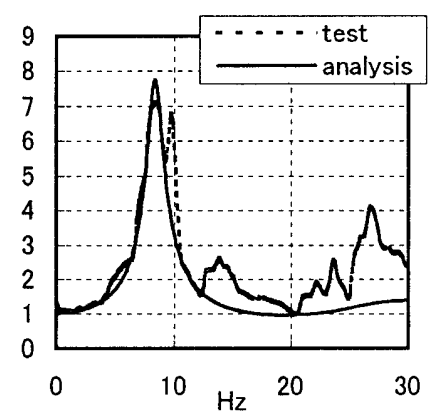

(a) $\mathrm{BH} 6 / \mathrm{SH} 5$
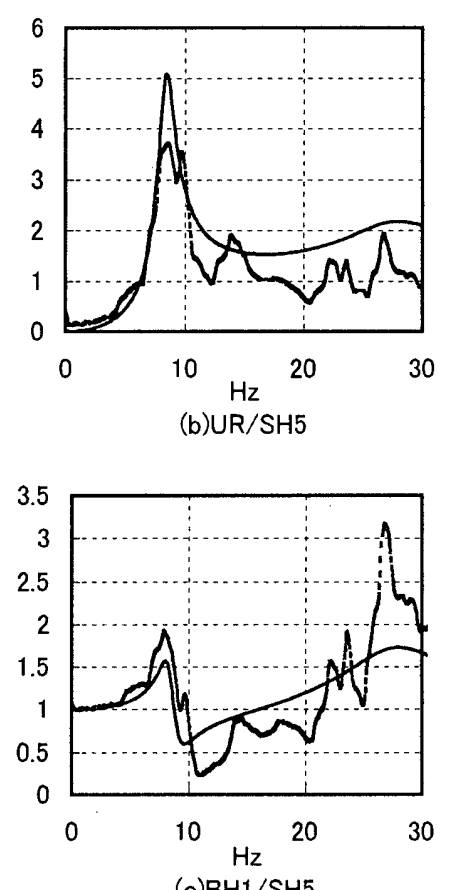

(c) $\mathrm{BH} 1 / \mathrm{SH} 5$

図15スペクトル比

$(100 \mathrm{~cm} / \mathrm{s} / \mathrm{s})$

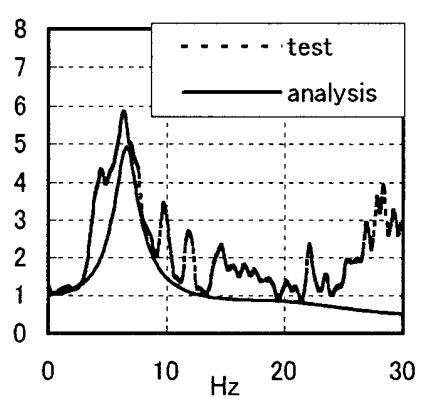

(a) $\mathrm{BH} 6 / \mathrm{SH} 5$

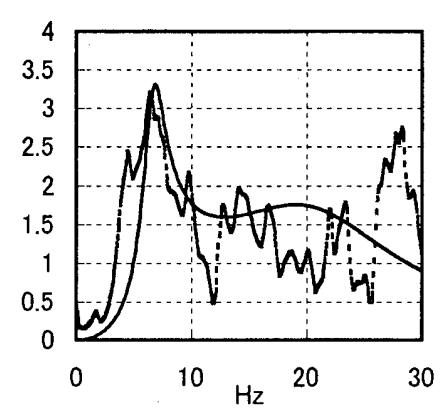

(b) UR/SH5

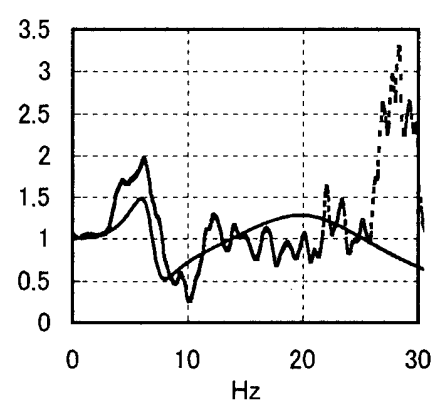

(c) $\mathrm{BH} 1 / \mathrm{SH} 5$

図16 スペクトル比 $(300 \mathrm{~cm} / \mathrm{s} / \mathrm{s})$

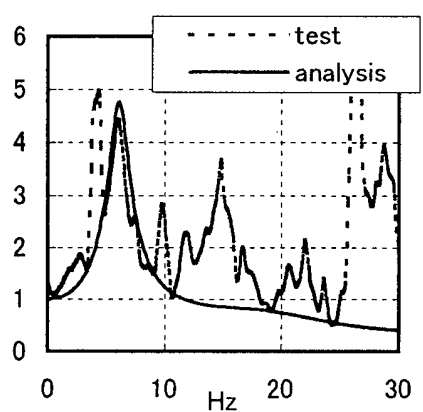

(a) $\mathrm{BH} 6 / \mathrm{SH} 5$

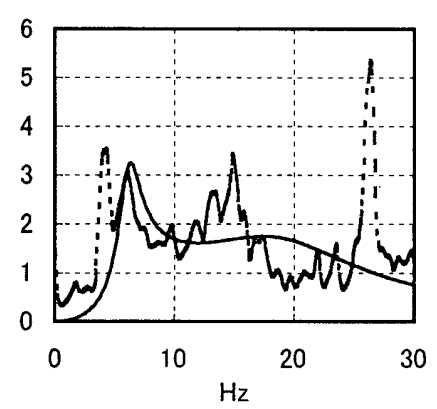

(b) UR/SH5

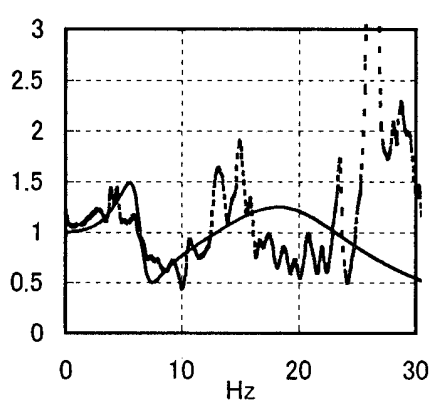

(c) $\mathrm{BH} 1 / \mathrm{SH} 5$

図17 スペクトル比 $(600 \mathrm{~cm} / \mathrm{s} / \mathrm{s})$ 
$1.07,0.77 \sim 0.94$ となっている。一次固有振動数, 最大态答加速 度において実験值と解析值の対応関係が調和的となる $\alpha$ は 0.4 で

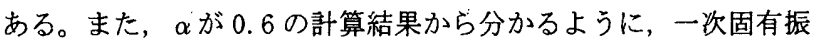
動数を推定する際の誤差が $8 \%$ 程度でも建物頂部の最大応答加速 度推定の誤差は $23 \%$ とかなり大きくなっており, 固有振動数を精 度よく評価することが重要であることがわかる。

以上のことから入力加速度值が大きい場合, 基礎と地表面との 相対変位の時刻歴の非定常性が強くなり, また, これと地盤の 入・反射波動場による歪の時刻歴との位相差が大きくなるため非 定常性を考慮する係数を一般的に使用されている值 (0.7 程度)よ り小さくする必要がある。なお，これ以降は式(5)における係数 を, $100 \mathrm{~cm} / \mathrm{s}^{2} お よ ひ ゙ ~ 300 \mathrm{~cm} / \mathrm{s}^{2}$ 入力の場合は $0.7,600 \mathrm{~cm} / \mathrm{s}^{2}$ 入力の 場合は 0.4 を用いた結果のみ示す。

図 11 に最大応答加速度分布の実験值と解析值を示す。図の縋 軸は模型地盤底面からの位置を示す。 $300 \mathrm{~cm} / \mathrm{s}^{2}$ 入力の場合, 解析 で応答值をやや過小に評価しているが，そのほかの場合も含めて 最大加速度值の分布形の実験值と解析值との対応は調和的であ る。図 12〜14 に建物頂部 (BH6) での時刻歴応答加速度の実験值と 解析值を示す。時刻歴においても実験值と解析值は調和的である。 図 15〜17 に建物各部での応答成分 (BH6: 建物頂部，UR: 建物頂部 での回転成分, $\mathrm{BHl}$ : 建物基礎) と地表面 (SH5) とのスペクトル比の 実験值と解析から得られた伝達関数を示す（ピック配置は図 2 参 照）。これより， $100 \mathrm{~cm} / \mathrm{s}^{2}$ 入力の場合, 解析で建物頂部での応答 をよく評価しているが，ロッキング成分は過大に，スウェイ成分 は過小に評価していることがわかる。 $300 \mathrm{~cm} / \mathrm{s}^{2}$ 入力の場合，ロッ キング成分は比較的よく評価されているが，建物頂部の応答およ びスウェイ成分はやや過小に評価されている。なお， $600 \mathrm{~cm} / \mathrm{s}^{2}$ 入 力の場合, 建物頂部の応答を示すスペクトル比で $4.0 \mathrm{~Hz}$ 付近にピ 一クがあるが，入力成分 (SH5) と出力成分 (BH6) の相関関数の值が 低いために 6.04Hz のピークを一次固有振動数だと判断した。こ の場合，建物頂部およびロッキング成分とも解析において比較的 よく評価しているが，スウェイ成分をやや過大に評価しているこ とになる。

\section{7. まとめ}

塑性地盤材料を用いて地盤・杭・建物連成系において振動台実 験を実施し，SR モデルによる地震応答解析を実施した。地盤バネ の算定にあたっては地盤の材料非線形性を考慮するために等価 線形化法を適用した。さらに，杭の水平変位による周辺地盤の非 線形性を考慮するために杭の水平剛性に対する静的解析結果を これに組み合わせ, 実験結果と解析結果との比較から解析手法の 妥当性について検討した。

これより以下の結論を得た。

1）地盤底面での入力加速度の最大值が $100,300,600 \mathrm{~cm} / \mathrm{s}^{2}$ と増加
するにしたがい，波動の入・反射場における地盤の最大歪みの平 均值は $0.0018 〜 0.018$ 程度に変化している。これにともなって連 成系一次固有振動数波は $8.25 \mathrm{~Hz}$ から $6.0 \mathrm{~Hz}$ 八，地表面に対する 建物での応答倍率は7.1 から 4.3 程度へ低下している。したがっ て $100 \mathrm{~cm} / \mathrm{s}^{2}$ 入力に比べて $600 \mathrm{~cm} / \mathrm{s}^{2}$ 入力の場合, 一次固有振動数 と応答倍率はそれぞれ $72 \% ， 61 \% に$ 低下している。

2) 一次固有振動数, 态答倍率, 建物頂部の最大応答加速度值につ いて解析值と実験值との比(解析值/実験值)はそれぞれ0.99〜 1.04，0.84〜1.09，0.94〜1.10 と工学的には十分な精度を持って いるといえる。しかしながら，入力加速度が大きい場合，等価線 形化法において地震動に対する応答の非定常性を考慮する係数 の值を小さくする必要がある。この係数を小さくする根拠として 入力加速度が増加すると，i）地盤と基礎との相対変位の振幅に おける非定常性が増大すること， ii）地盤の入・反射波動場によ る歪みと基礎と地盤の相対変位による地盤歪みとの位相差が大 きくなること、をあげた。

\section{参考文献}

1) Miura, K., Masuda, K., Maeda, T. and Kobori, T. : Nonl inear Dynamic Impedance of Pile Group Foundation, Proc. 3rd Int. Conf. On Recent Advances in Geotechnical Earthquake Eng. And Soil Dynamics, pp. 417 $\sim 422,1995$

2）日下部馨，安田拓矢，前田幸典：土の非線形を考慮した杭基礶一地盤采 の振動特性, 第 9 回日本地震工学シンポジウム, pp. 1219 1224, 1994 3）千々岩健児，烟村洋太郎，鉿木徹郎：プラスチシンによる圧延および連 続鋳造鋳片の応カシミュレーションの方法，鉄と銅，第 66 年，第 8 号, pp. 1103 1112, 1980

4）石原研而：土質動力学の基礎，鹿島出版会，p. 298, 昭和 53 年 5) 计村知明，田守伸一郎，北川良和，飯場正紀：弾塑性地盤材料を用いた 地盤・杭・建物連成系の振動台実験，日本建築学会北陸支部研究報告集， 第 36 号, pp. 125 128, 1993

6）北川良和，松島 豊，村上雅也，井上芳生，飯場正紀，田守伸一郎，鹿 䳋俊央, 岡野 㓣: 地盤・建物連成系におけるせん断力分布保数，(その 1) 〜 (その 3), 日本建筑学会大会学術講演梗概集, B, 構造 I，pp. 817〜 822, 昭和 63 年 10 月

7) Novak, M. and Nogami, T. : Soil-Pile Interaction in Horizontal Vibration, Earthquake Engineering and Structural Dynamics, Vol.5, pp. 263 281, 1977

8）井上芳夫，大澤 㭌，松島 豊ほか：公団住宅の入力評価に関する研究 (その 6,7), 日本建策学会大会学術講演梗概集, B, 構造 I, pp. 591 594,1987

9) Novak, M. : Vertical Vibration of Floating Piles, Proceedings of the American Society of Civil Engineers, Vol. 103, EM1, pp. 153 168, 1977

（1999年10月 5 日原稿受理，1999年12月 20 日採用決定） 